\title{
Production of biodegradable starch nanocomposites using cellulose nanocrystals extracted from coconut fibers
}

\author{
Jamile Costa Cerqueira ${ }^{1}$, Josenai da Silva Penha' ${ }^{1}$, Roseane Santos Oliveira ${ }^{1}$, Lilian Lefol Nani Guarieiro², \\ Pollyana da Silva Melo², Josiane Dantas Viana ${ }^{3}$ and Bruna Aparecida Souza Machado** \\ ${ }^{1}$ Applied Research Laboratory of Food and Biotechnology, Department of Food and Beverages, \\ Centro Universitário - SENAI-CIMATEC, Salvador, BA, Brazil \\ ${ }^{2}$ Integrated Laboratory of Applied Research in Chemistry, Department of Automotive, \\ Centro Universitário - SENAI-CIMATEC, Salvador, BA Brazil \\ ${ }^{3}$ Materials Laboratory, Department of Materials, Centro Universitário - SENAI-CIMATEC, \\ Salvador, BA, Brazil \\ *brunam@fieb.org.br
}

\begin{abstract}
Different polymeric matrices have been investigated for use in the development of biodegradable films. The incorporation of cellulose nanocrystals in such films has particularly attracted attention because of the potential for achieving improved properties of starch nanocomposites. In the present study, cellulose nanocrystals were extracted from coconut fibers and incorporated in cassava and potato starch films at different concentrations. The properties of the different nanobiocomposite films were comparatively evaluated, including their barrier and mechanical properties. All the films, regardless of the nanocrystal concentration, were found to exhibit low solubility in water, with increased moisture content particularly observed in the films with higher nanocrystal concentrations. The potato starch film with the lowest nanocrystal concentration was found to exhibit the best mechanical properties. The observations of this study indicated that the source of the starch and the nanocrystal concentration determined the properties of the nanobiocomposite films.
\end{abstract}

Keywords: lignocellulosic fiber, biodegradable film, polymeric matrix, nanocrystal.

\section{Introduction}

Plastics are the most commonly used materials in the food industry, owing to their moldability, manageability, low cost, and suitable mechanical and chemical properties ${ }^{[1]}$. However, the diversity of resins used for their production poses challenges to their separation for reuse ${ }^{[2]}$. This has contributed to the environmental problems associated with discarded plastic packaging, with the significant buildup of residues requiring about $100-450$ years for their natural decomposition $^{[3]}$. The increasing demand for environmental preservation has thus necessitated research into alternatives to conventional plastics, such as varieties derived from petroleum derivatives using biodegradable and ecologically friendly materials.

The technological adaption of biomaterials, particularly polymers, for the development of flexible films has been widely studied in recent years ${ }^{[4-6]}$. Several biopolymers such as polysaccharides, proteins, and lipids have been utilized as polymeric matrixes for the development of alternative biodegradable packaging, owing to their availability, renewability, low cost, environmental friendliness, and biodegradability ${ }^{[7-9]}$. Among such agriculturally sourced materials, starch is considered to be favorable for the development of biocomposites ${ }^{[10,11]}$. Starch films are particularly characterized by transparency, non-toxicity, and low cost. However, they also have some limitations, the most prominent of which are low flexibility, high permeability to water vapor ${ }^{[2,12]}$, and inadequate mechanical and barrier resistance. This causes them to fall short of market expectations, especially in the food industry. Consequently, several studies have been conducted on the use of reinforcing additives such as fibers ${ }^{[13,14]}$ and cellulose nanocrystals ${ }^{[15-17]}$ to improve the mechanical, thermal, and barrier properties of starch-based films.

Cellulose is the most important polymer and is used in various fields, especially because of its availability, biocompatibility, and biodegradability ${ }^{[18,19]}$. Cellulose fibers have an inherent structural hierarchy originating from their differing biological sources. The production of cellulose nanocrystals from different lignocellulosic fibers has attracted interest in the scientific and industrial community in recent years. This has been owing to their mechanical and thermal properties, cost effectiveness, and versatility ${ }^{[20,21]}$. Nanocrystals are generally characterized by high solidity and crystallinity, which afford sustainability. When incorporated in films with renewable polymeric matrixes, they produce total biodegradable composites ${ }^{[22]}$ referred to as nanobiocomposites. As with any composite material, the properties of the nanobiocomposites depend on the properties of the individual components (matrix and reinforcement), the composition (volumetric fractions of the components), the morphology of each constituent phase (spatial arrangement, dimensions, and crystallinity), and the interfacial properties ${ }^{[23]}$.

It is important to highlight that the development of new composites with natural fiber reinforcement is quite promising, bearing in mind that, in addition to the renewability of the 
fiber sources, they also cost less than synthetic fibers ${ }^{[24,25]}$. Incidentally, Brazil is acknowledged as one of the largest agricultural producers in the world, contributing a large part of the millions of tons of lignocellulosic biomass produced globally from different sources ${ }^{[23]}$. The green coconut bark is an important source of natural fiber, and its utilization for the production of cellulose nanocrystals offers the benefit of reduced disposal of biomass ${ }^{[25-27]}$.

Further, it should be noted that the use of biodegradable packaging in the food industry promises to enhance the preservation of the packaged products. It would also lead to the creation of new consumer markets as the differentiated biodegradable properties of the films fit new consumer profiles, especially those who are prepared to pay more for products or services with a green stamp (a certificate granted to products manufactured for sustainable development) ${ }^{[28,29]}$.

It is noteworthy that recent studies have highlighted the benefits of incorporating cellulose nanocrystals in flexible films produced from cassava starch, namely, the improved properties afforded by the produced biodegradable starch nanocomposites ${ }^{[5,6,10,12]}$. In the present study, we incorporated cellulose nanocrystals produced from green coconut fiber in flexible films with polymeric matrixes of tapioca starch and potato starch, respectively. We evaluated the effects of the starch source and the concentration of the cellulose nanocrystals on the properties of the films, and determined the best matrix and nanocrystal concentration. Glycerol was used as plasticizer in the development of the flexible films. The objective of the study was to characterize green coconut fiber cellulose nanocrystals with respect to their size.

\section{Materials and Methods}

\subsection{Extraction of cellulose from green coconut fiber}

The extraction of the cellulose pulp from the green coconut fiber was performed based on the works of Rosa et al. ${ }^{[26]}$, Samir et al. ${ }^{[30]}$, and Machado et al. ${ }^{[5]}$. The coconut fibers were dried in a greenhouse and ground in a liquidizer to obtain a fine particulate. The particulate was further dried and $30 \mathrm{~g}$ of it was washed by constant agitation for $4 \mathrm{~h}$ in $1.2 \mathrm{~L}$ of a solution of $2 \% \mathrm{NaOH}$ at $80^{\circ} \mathrm{C}$. The fine particulate was then filtered and the washing process was repeated three more times to completely remove the water-soluble agents. The filtered particulate was subsequently further washed in distilled water to obtain the cellulose pulp. This was followed by delignification (or whitening) of the pulp using a mixture of $0.3 \mathrm{~L}$ of $1.7 \%$ sodium hypochlorite and $0.3 \mathrm{~L}$ of a buffer solution. The cellulose pulp was constantly agitated in the mixture for $6 \mathrm{~h}$ at $80^{\circ} \mathrm{C}$, and then filtered and dried in a greenhouse. It was finally pulverized in a mill (Cadense Ltd, Brazil).

\subsection{Preparation of cellulose nanocrystals}

The cellulose nanocrystals were prepared by acid hydrolysis using $64 \% \mathrm{H}_{2} \mathrm{SO}_{4}^{[5,6,26]}$, with $12 \mathrm{~mL}$ of cellulose pulp per gram of the acid subjected to constant agitation for $5 \mathrm{~min}$ at $50^{\circ} \mathrm{C}$. After acid hydrolysis, the samples were filtered and their concentrations adjusted. The samples were then centrifuged for $10 \mathrm{~min}$ at $4400 \mathrm{rpm}$ and $10^{\circ} \mathrm{C}$ to separate the crystals. This procedure was repeated eight times, when no more supernatant was produced. The suspensions were then dialyzed using the D9777-100 FTO cellulose membrane with 12.000 Da cut off (Sigma-Aldrich) until their $\mathrm{pH}$ was approximately 7 , after which the samples were placed in an ultrasonic bath for $20 \mathrm{~min}$.

\subsection{Preparation of nanobiocomposites}

The nanobiocomposites were prepared by the casting method, which is used for the preparation and drying of films. The process involved the preparation of a film-forming solution in which the polymeric matrix $(4 \%, \mathrm{~g} / 100 \mathrm{~g})$ manioc starch (Cargill Agrícola SA) or potato starch — and glycerol (Synth ${ }^{\circledR}, 1.0 \%$, g/100 g) were initially dissolved. The solution was prepared with distilled water. The mixture was then added to a suspension of the cellulose nanocrystals containing varying amounts of the nanocrystals $(0.5 \%$, $1.0 \%$, and $1.5 \%(\mathrm{~g} / 100 \mathrm{~g})$ ) (Table 1$)$. The new mixtures were then heated to the gelatinization temperature of the starch $\left(\sim 70^{\circ} \mathrm{C}\right)$ under constant manual agitation. $45 \mathrm{~g}$ of the mixtures was then weighed in polystyrene Petri dishes and dehydrated in a greenhouse under airflow $\left(35 \pm 2^{\circ} \mathrm{C}\right)$ for $18-20 \mathrm{~h}$. Other films were produced without the addition of cellulose nanocrystals for use as controls. Before their characterization, the prepared nanobiocomposites were stored at $60 \%$ humidity and $23^{\circ} \mathrm{C}$ for 10 days in a desiccator containing a saturated solution of sodium chloride.

\subsection{Characterization of coconut fibers and cellulose nanocrystals}

The main components of the fibers obtained from green coconut bark (lignin, hemicellulose, and cellulose) were characterized using the ANKOM A200 Fiber Analyzer. The methodology proposed by Van Soest et al. ${ }^{[31]}$ and Goering and Van Soest ${ }^{[32]}$ was employed. The fibers and cellulose were also characterized using a scanning electron microscope (SEM) (model JEOL JSM-6390LV). The fibers and cellulose samples used for the SEM characterization were metalized with gold in a "sputter coater" (model SCD 50, Balzers) using argon plasma, and then left to rest for $24 \mathrm{~h}$.

To determine the birefringence of the suspensions of the cellulose nanocrystals in water, two films of crossed polarizers were used. The polarizer films were positioned perpendicularly to each other and a light was directed at one of them. The suspension sample was then interpolated between the two films ${ }^{[33]}$.

Table 1. Design of the experimental nanobiocomposites.

\begin{tabular}{|c|c|c|c|c|}
\hline Formulation & $\begin{array}{c}\text { Manioc } \\
\text { starch } \\
(\%, \mathrm{~g} / \mathbf{1 0 0} \mathrm{g})\end{array}$ & $\begin{array}{c}\begin{array}{c}\text { Potato } \\
\text { starch }\end{array} \\
(\%, \mathrm{~g} / 100 \mathrm{~g})\end{array}$ & $\begin{array}{c}\text { Cellulose } \\
\text { nanocrystals } \\
(\%, \mathrm{~g} / \mathbf{1 0 0} \mathrm{g})\end{array}$ & $\begin{array}{c}\text { Glycerol } \\
(\%, \mathrm{~g} / 100 \mathrm{~g})\end{array}$ \\
\hline FM05 & 4.0 & - & 0.5 & 1.0 \\
\hline FM10 & 4.0 & - & 1.0 & 1.0 \\
\hline FM15 & 4.0 & - & 1.5 & 1.0 \\
\hline FB05 & - & 4.0 & 0.5 & 1.0 \\
\hline FB10 & - & 4.0 & 1.0 & 1.0 \\
\hline FB15 & - & 4.0 & 1.5 & 1.0 \\
\hline Control FM & 4.0 & - & - & 1.0 \\
\hline Control FB & - & 4.0 & - & 1.0 \\
\hline
\end{tabular}


The suspension of the coconut cellulose nanocrystals was examined by an SEM to determine the crystal length $(L)$, diameter $(D)$, and aspect ratio $(L / D)$, and the state of the aggregation of the nanocrystals. The nanocrystals were visualized by coloring with $2 \%$ uranyl acetate (UA). The coloring was done by mixing the suspension of the cellulose nanocrystals with an equal volume of UA. $10 \mu \mathrm{L}$ of the mixture was then distributed through 400-mesh copper grids and left to stand for 30-60 s. The grids were subsequently dried and visualized by a transmission electron microscope (TEM) (BX-51, Olympus) operated in the clear field mode at $80 \mathrm{kV}$. The length and width of the nanocrystals were directly measured from the transmission electron micrograph. The mean and standard deviation for 30 measurements were determined.

\subsection{Characterization of nanobiocomposites and controls}

The thicknesses of each pre-packaged nanobiocomposite film $\left(60 \%\right.$ humidity, $\left.25^{\circ} \mathrm{C}\right)$ were determined by calculating the average thickness for six measurements at random points. A flat-head digital micrometer (Mitutoyo) with a resolution of $1 \mu \mathrm{m}$ was used for the measurements. The water activity (aw) of the nanobiocomposite film was also measured using a Lab Master decagon with an electrolytic measurement cell (CM-2, TECNAL), with the temperature controlled to $25^{\circ} \mathrm{C}^{[34,35]}$. Further, the humidity and total solid content of the nanobiocomposite film were determined by infrared drying using a Shimadzu infrared scale, with the intensity of the radiation adjusted to raise the temperature of the sample to $105^{\circ} \mathrm{C}$.

The water solubilities of the different formulations were determined using the method proposed by Gontard et al. ${ }^{[36]}$. The traction assays were performed using a texture analyzer (model CT310K, Brookfield) with a maximum load of $10 \mathrm{kN}$. The ASTM D-882 standard that was adopted for the assays stipulates a loading speed of $0.50 \mathrm{~mm} / \mathrm{s}$, temperature of $25^{\circ} \mathrm{C}$, trigger load of $7 \mathrm{~g}$, test probe tip of TA3/100, and the use of a TA/TPB probing device. The traction assays were performed using six proof bodies for each sample. The proof bodies were of length $80 \mathrm{~mm}$ and width $25 \mathrm{~mm}$, and their strength was calculated by dividing the maximum applied force by the area of the film (width $\times$ thickness). The strain at breakage was calculated by dividing the final length by the projection of the probe tip $(50 \mathrm{~mm})$ and multiplying by $100^{[37]}$.

\subsection{Statistical analysis}

The results of the above investigations were expressed in the form of mean \pm standard deviation $(n=3)$. Statistica ${ }^{\circledR}$ 6.0 (StatSoft, Tulsa) was used for the statistical analyses of the results. Analysis of variance (ANOVA) and Tukey's tests were used to determine the significant differences between means $(p<0.05)$.

\section{Results and Discussions}

\subsection{Characterization of coconut fibers and nanocrystals}

Vegetable fibers are mainly composed of cellulose, hemicellulose, and lignin, together with other smaller constituents. The physical and chemical properties of a particular fiber depend on its source and processing. The analysis of the chemical composition of the green coconut fiber in this study revealed cellulose, lignin, and hemicellulose contents of $32.0 \%, 38.0 \%$, and $0.25 \%$, respectively (Table 2 ). Trugilho et al. ${ }^{[38]}$ reported that the lignin and cellulose contents of young plants are variable, and only stabilize with maturation. Corradini et al. ${ }^{[39]}$ particularly found that the lignin and cellulose contents of a young green coconut fiber varied within $37.2 \%-43.9 \%$ and $31.5 \%-37.4 \%$, respectively. Similar results were obtained by Rosa et al. ${ }^{[26,40]}$, who highlighted the high lignin content of green coconut fiber (Table 2) and the potential for its use in the reinforcement of polymeric materials ${ }^{[39]}$.

Figure 1 shows SEM images of green coconut fiber (Figure 1A) and the extracted cellulose (Figure 1B). The micrographs of the in natura fiber (Figure 1A) reveal rugged surfaces covered by layers of wax and extracts, as well as amorphous constituents such as lignin and hemicellulose. The micrographs of the whitened cellulose (Figure 1B) reveal the presence of cellulose fibrils and provide evidence of disaggregated ruggedness, which was due to the conversion of cellulosic elements to fibrils by the removal of poliosis and lignin during the whitening process. Pores and/or orifices can also be observed on the rugged surface. As also evidenced by Alemdar and Sain ${ }^{[18]}$, these images suggest that the chemical treatment partially removed impurities such as hemicellulose and lignin, which are the "compacting" components of the fibers. The efficient removal of lignin by the whitening of the fibers is extremely important to obtaining nanocrystals by hydrolysis.

The visualization of the suspension of the cellulose nanocrystals obtained from the green coconut fiber (concentration of $0.06 \mathrm{~g} / 10 \mathrm{~mL}$ ) through polarizers revealed a nematic phase, which was directly produced by the light birefringence and is considered to confirm the presence of nanocrystals (Figure 2). Mesquita et al. ${ }^{[41]}$ and Alves et al. ${ }^{[17]}$ similarly used crossed polarizers to visualize the birefringence phenomenon in a $4 \%$ suspension of cellulose nanocrystals obtained from eucalyptus. Birefringence (or optical anisotropy) is a property of transparent crystals that enables them to decompose a light ray into two crossed polarized rays. Observation of the birefringence in a cellulose nanocrystal suspension is thus an effective means of evaluating the nanocrystal formation ${ }^{[42]}$, and hence assessing the efficiency of the hydrolysis process. It has been observed that suspended cellulose nanocrystals exhibit a tendency to align themselves, probably due to their high solidity and length-to-diameter ratio ${ }^{[30]}$. It is also very important to determine whether the cellulose nanocrystals are well dispersed in suspension, because this is required to achieve good results when they are incorporated in a polymeric matrix for mechanical reinforcement $t^{[43,44]}$.

Figure 3 shows the TEM micrographs of the cellulose nanocrystals, from which the length $(L)$, diameter $(D)$,

Table 2. Chemical composition of green coconut fiber.

\begin{tabular}{ccc}
\hline Cellulose (\%) & Lignin (\%) & Reference \\
\hline 32.0 & 38.0 & This study \\
32.0 & 40.0 & Rosa et al. ${ }^{[40]}$ \\
37.0 & 32.5 & Rosa et al. $^{[26]}$ \\
$31.5 \%-37.4 \%$ & $37.2 \%-43.9 \%$ & Corradini et al. $^{[39]}$ \\
\hline
\end{tabular}




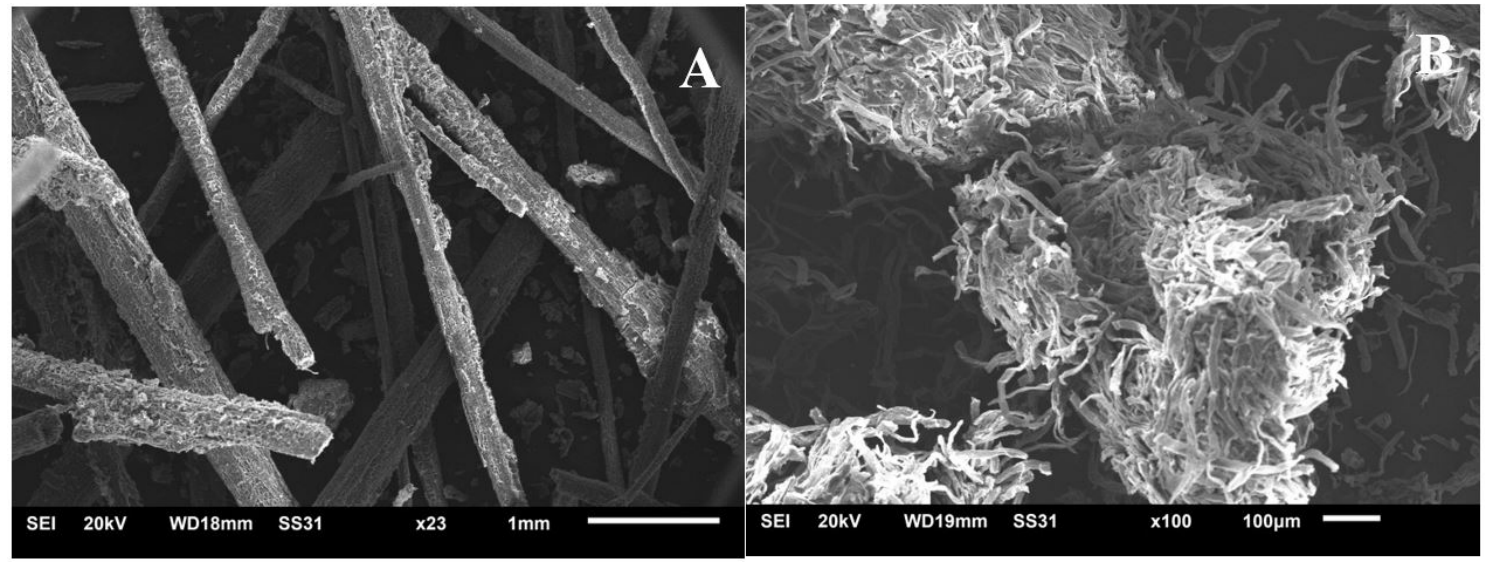

Figure 1. SEM images of the (A) in natura green coconut fiber and (B) extracted cellulose (B) (Ranges of $1 \mathrm{~mm}$ and $100 \mu \mathrm{m}$ ).

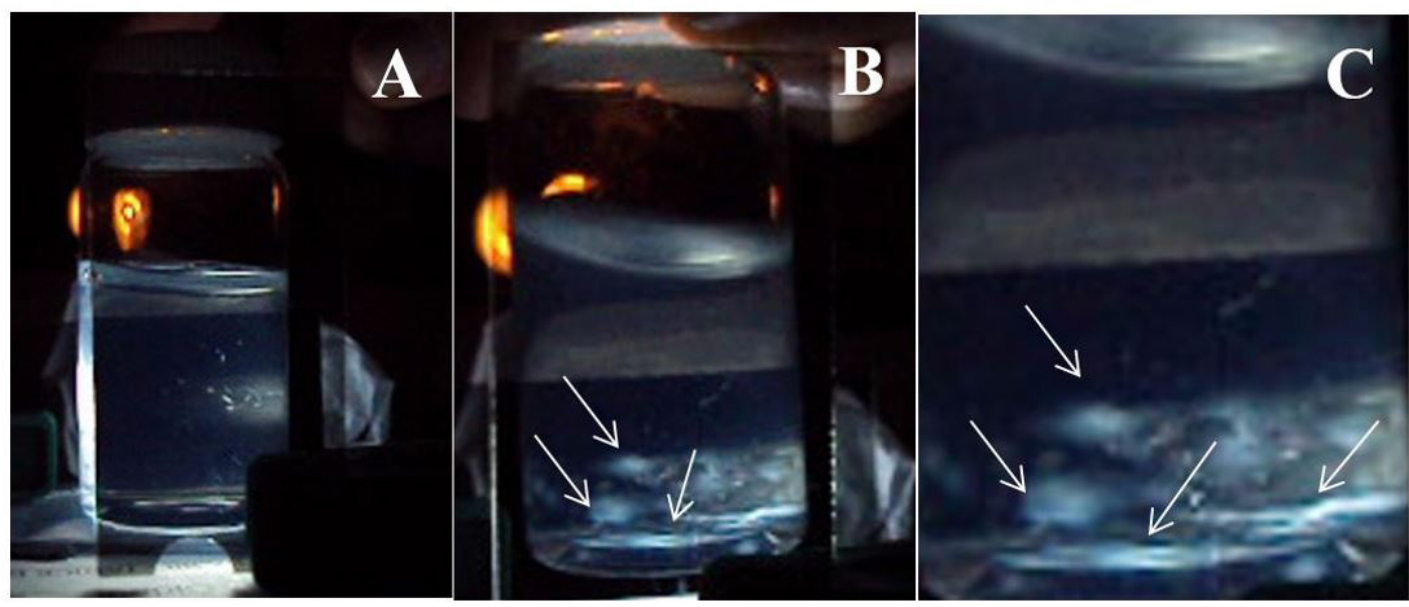

Figure 2. Illustration of the suspension of cellulose nanocrystals obtained from green coconut fiber: (A) positions of the Polaroid and sample; (B) sample agitation by birefringence evidencing the presence of the nanocrystals; and (C) magnification of the image in (B) (the arrows indicate the locations of the birefringence phenomena).
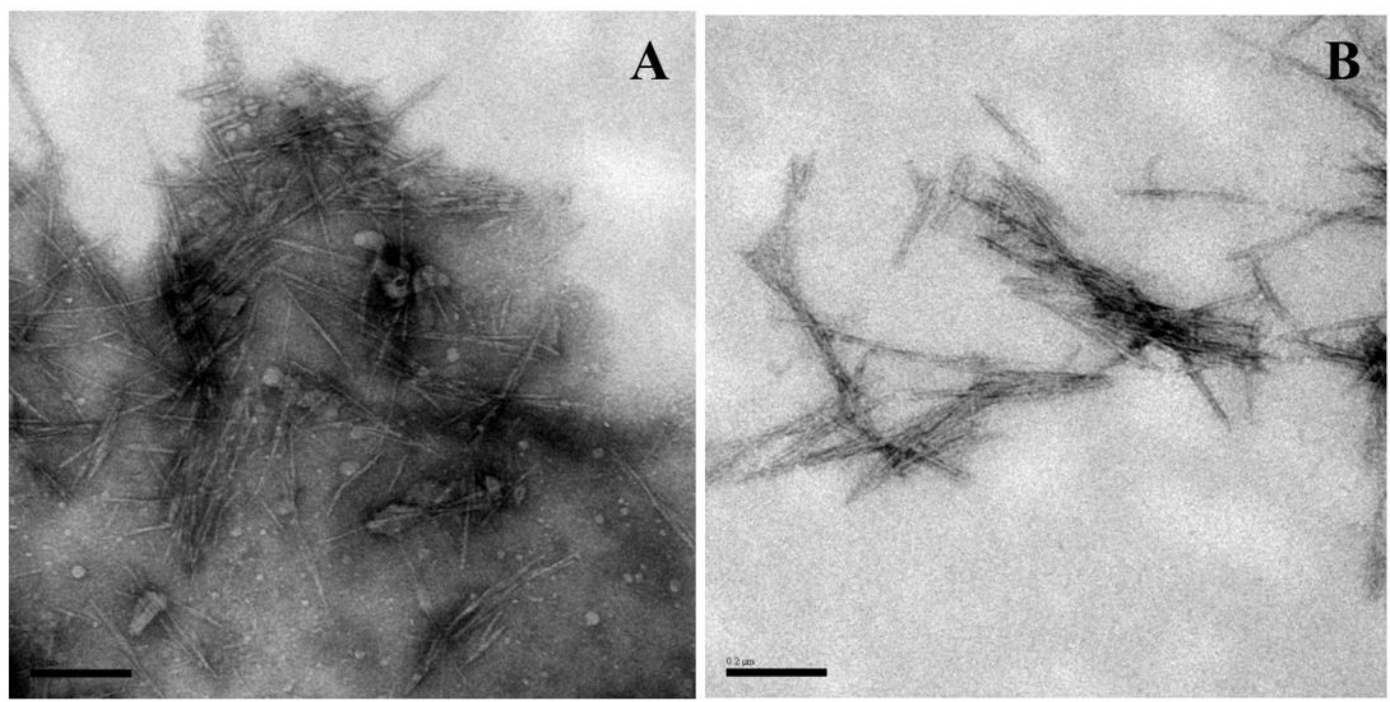

Figure 3. TEM images of the nanocrystals obtained from green coconut fiber cellulose, showing (A) agglomeration of the nanocrystals and (B) some isolates (Range: $200 \mathrm{~nm}$ ). 
and aspect ratio $(L / D)$ of the nanocrystals and their state of aggregation were determined. The images confirm the effectiveness of the acid hydrolysis used to produce the cellulose nanocrystals from the green coconut fiber. The images indicate that the aqueous suspensions contained needle-like nanocrystals, consisting primarily of individual fibrils and their aggregates. The cellulose nanocrystals were formed by nanoparticles containing several hydroxyl groups on their surfaces and with a large specific area. Aggregation of the nanocrystals was thus common, as expected, mainly due to the strong hydrogen links formed between cellulose nanoparticles ${ }^{[45]}$.

The coconut cellulose nanocrystals examined in this study had length $L$ values of 89-320 nm (average of $264.9 \pm 23.0 \mathrm{~nm}$ ) and average diameter $\mathrm{D}$ of $8.10 \pm 1.21 \mathrm{~nm}$. These results agree well with previously obtained data for cellulose nanocrystals extracted from coconut fibers, namely, $L$ values of $80-500 \mathrm{~nm}$ and $D$ values of $4-9 \mathrm{~nm}^{[5,26,40]}$. Silva et al. ${ }^{[45]}$ also reported an $L$ value of $145 \mathrm{~nm}$ and average $D$ of $1.5 \mathrm{~nm}$ for nanocrystals obtained from eucalyptus, while Costa et al. ${ }^{[6]}$ reported $L=157 \mathrm{~nm}$ and average $D=5.7 \mathrm{~nm}$ for nanocrystals obtained from licuri fiber. The average aspect ratio $(L / D)$ determined in the present study was $32.7 \pm 5.1$, which confirms the potential of the coconut cellulose nanocrystals for use as reinforcement agents for polymeric matrixes in the development of composites, as proposed by Rosa et al. ${ }^{[40]}$ and Machado et al. ${ }^{[5]}$, who reported $L / D$ values of $39 \pm 16$ and $38.9 \pm 4.7$, respectively.

\subsection{Characterization of nanobiocomposites}

The films produced from the six formulations of nanobiocomposites prepared in this study using different starch types (manioc and potato), as well as the control films, were examined to determine their barrier properties (thickness, water activity, water solubility, and humidity) and mechanical properties (strength and strain at breakage). An attempt was also made to evaluate how these parameters were affected by the addition of the coconut fiber cellulose nanocrystals. The produced starch films were found to be homogeneous, transparent, and visually attractive. Figure 4 shows an example of the manioc starch film with $0.5 \%$ nanocrystals (FM05). The determined barrier and mechanical properties of the different films are given in Tables 3 and 4 .

Control of the thickness is extremely important to maintaining uniformity of the films and comparing their propertie ${ }^{[46]}$. Significant difference was observed between the average thicknesses of the FM10 $(0.08 \mathrm{~mm})$ and FB $(0.12 \mathrm{~mm})$ control films, as well as among their respective samples. The potato starch films were also found to be thicker than the manioc starch films (see Table 3). The mechanism of the film formation is known to be dependent on the concentration of the solids in the formulation and the amylose content. The potato starch formulation appeared to be more viscous than that of the manioc starch, suggesting a higher amylose concentration of the former, and hence the thicker films. With regard to the formulations containing the same matrix, namely, the same starch content and plasticizer concentration, variation of the drying method (casting) directly resulted in varying film thicknesses, as previously reported ${ }^{[6,47-49]}$. Fakhouri et al. ${ }^{[37]}$ obtained varying film thicknesses between 0.039 and $0.081 \mathrm{~mm}$ for starch films plasticized with gelatin, while Reis et al. ${ }^{[14]}$ obtained thicknesses of $0.11-0.12 \mathrm{~mm}$ for manioc starch films containing mango pulp and mate extract.

The water solubility of a film is an important property that determines its applicability for food packaging ${ }^{[50]}$. In some cases, total water solubility could be beneficial, such as in the case of semifinished food products that require further cooking. However, when the food item is liquid or aqueous, highly soluble polymeric films are undesirable ${ }^{[51]}$. The percentage solubility of the nanocomposites developed

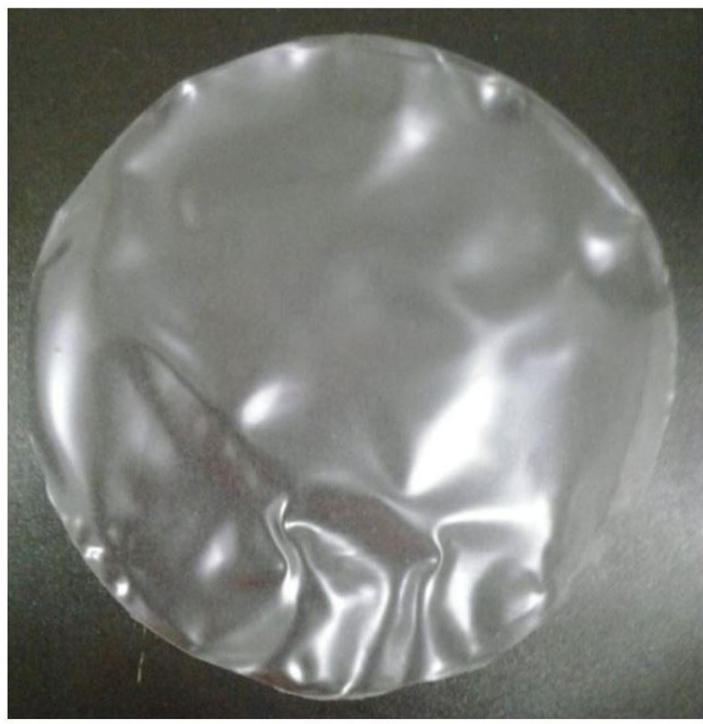

Figure 4. Nanobiocomposites obtained by the incorporation of $0.5 \%$ coconut cellulose nanocrystals in a manioc starch matrix plasticized with glycerol (FM05).

Table 3. Barrier properties (average \pm standard deviation) of the films produced using different nanobiocomposite formulations.

\begin{tabular}{cccccc}
\hline Formulation & EP & aw & UM & ST & SL \\
\hline Control FM & $0.08 \pm 0.01^{\mathrm{a}}$ & $0.65 \pm 0.01^{\mathrm{a}}$ & $15.31 \pm 0.78^{\mathrm{a}}$ & $84.68 \pm 0.78^{\mathrm{a}}$ & $30.55 \pm 0.83^{\mathrm{a}}$ \\
FM05 & $0.08 \pm 0.01^{\mathrm{a}}$ & $0.58 \pm 0.01^{\mathrm{b}}$ & $16.21 \pm 0.97^{\mathrm{b} . c}$ & $83.79 \pm 0.97^{\mathrm{b} \cdot \mathrm{c}}$ & $30.54 \pm 0.83^{\mathrm{a}}$ \\
FM10 & $0.08 \pm 0.01^{\mathrm{b}}$ & $0.68 \pm 0.01^{\mathrm{c}}$ & $18.33 \pm 1.29^{\mathrm{b}}$ & $81.67 \pm 1.29^{\mathrm{b}}$ & $31.56 \pm 0.80^{\mathrm{b}}$ \\
FM15 & $0.09 \pm 0.02^{\mathrm{c}}$ & $0.71 \pm 0.01^{\mathrm{c}}$ & $17.98 \pm 0.26^{\mathrm{b}}$ & $82.01 \pm 0.26^{\mathrm{b}}$ & $32.16 \pm 0.65^{\mathrm{c}}$ \\
Control FB & $0.12 \pm 0.02^{\mathrm{d}}$ & $0.69 \pm 0.01^{\mathrm{c}}$ & $16.60 \pm 0.50^{\mathrm{c}}$ & $83.39 \pm 0.50^{\mathrm{c}}$ & $28.30 \pm 0.78^{\mathrm{d}}$ \\
FB05 & $0.09 \pm 0.01^{\mathrm{c}}$ & $0.66 \pm 0.02^{\mathrm{c}}$ & $18.87 \pm 0.61^{\mathrm{b}}$ & $81.12 \pm 0.61^{\mathrm{b}}$ & $29.52 \pm 0.46^{\mathrm{d}}$ \\
FB10 & $0.10 \pm 0.02^{\mathrm{e}}$ & $0.70 \pm 0.01^{\mathrm{c}}$ & $18.26 \pm 0.91^{\mathrm{b}}$ & $81.74 \pm 0.91^{\mathrm{b}}$ & $25.30 \pm 0.36^{\mathrm{e}}$ \\
FB15 & $0.10 \pm 0.01^{\mathrm{e}}$ & $0.68 \pm 0.02^{\mathrm{c}}$ & $18.46 \pm 0.38^{\mathrm{b}}$ & $81.53 \pm 0.38^{\mathrm{b}}$ & $29.17 \pm 0.65^{\mathrm{d}}$ \\
\hline
\end{tabular}

EP - thickness (mm), aw - water activity (\%), UM - humidity (\%), ST - total solids (\%), SL -solubility (\%). No significant difference between values with the same superscript letter in a column $(p>0.05)$, according to Tukey's test with $95 \%$ confidence. 
Table 4. Mechanical properties (average \pm standard deviation) of the films produced using different nanobiocomposite formulations.

\begin{tabular}{ccccc}
\hline Formulation & ST & $\uparrow$ ST & $\boldsymbol{\varepsilon}$ & $\downarrow \boldsymbol{\varepsilon}$ \\
\hline Control FM & $3.23 \pm 0.51^{\mathrm{a}}$ & --- & $26.39 \pm 5.04^{\mathrm{b}}$ & -- \\
FM05 & $3.65 \pm 0.68^{\mathrm{b}}$ & 13.00 & $23.90 \pm 1.67^{\mathrm{c}}$ & 9.43 \\
FM10 & $4.41 \pm 0.30^{\mathrm{c}}$ & 36.53 & $17.54 \pm 0.80^{\mathrm{d}}$ & 33.53 \\
FM15 & $3.80 \pm 0.94^{\mathrm{b}}$ & 17.64 & $24.71 \pm 3.18^{\mathrm{bc}}$ & 6.36 \\
Control FB & $4.07 \pm 0.20^{\mathrm{d}}$ & --- & $30.81 \pm 4.44^{\mathrm{a}}$ & --- \\
FB05 & $8.20 \pm 0.52^{\mathrm{e}}$ & 101.47 & $23.71 \pm 3.54^{\mathrm{c}}$ & 23.04 \\
FB10 & $5.43 \pm 0.24^{\mathrm{f}}$ & 33.41 & $26.50 \pm 3.75^{\mathrm{b}}$ & 13.98 \\
FB15 & $4.09 \pm 0.64^{\mathrm{d}}$ & 0.31 & $30.40 \pm 1.77^{\mathrm{a}}$ & 1.33 \\
\hline
\end{tabular}

ST - strength (MPa), $\uparrow S T$ - increase in strength relative to control (\%), $\varepsilon$ - strain at breakage (\%), $\downarrow \varepsilon$ - decrease in strain at breakage relative to control (\%). No significant difference between values with the same superscript letter in a column $(p>0.05)$, according to Tukey's test with $95 \%$ confidence.

in the present study varied between 25.30 (FB10) and 32.16 (FM15), and may thus be considered as low-solubility films ${ }^{[52]}$. This indicates that they can be used to package a wide variety of food items, provided that their overall performance satisfies relevant legislation.

It was not possible to determine a direct effect of the nanocrystals on the water solubility of the present films. However, the films containing the nanocrystals generally exhibited higher water solubility compared to the control films, although a lower solubility was observed for the film produced from the potato starch matrix containing $10 \%$ nanocrystals. The present solubility results are similar to those obtained by Jiang et al. ${ }^{[50]}$ for films produced from pea starch reinforced with potato starch nanoparticles. Considering the observations of Rubentheren et al. ${ }^{[53]}$ and Pagno et al. ${ }^{\left[{ }^{[4]}\right.}$ all the films containing cellulose nanocrystals were expected to exhibit significantly lower solubility. This is based on the stronger resistance of the films compared to the control films (Table 4), mainly due to the interaction between the nanocrystals and the starch chains. However, only the film produced using formulation FB10 exhibited such decreased solubility.

With regard to the water activity (aw) of the films, the values were found to vary between 0.58 (FM05) and 0.71 (FM15), with significant differences observed for only the films produced from the manioc starch formulations. The aw was not found to be directly affected by the nanocrystal content of the films. The property is, however, an important consideration for food packaging ${ }^{[5]}$ because the water content affects the growth of microorganisms. The property is thus directly related to the quality conservation of the packaged product. Silva et al. ${ }^{[5]}$ found that starch films containing cellulose nanocrystals had aw values of $0.46-0.63$, which substantiates the present observation that formulations containing higher percentages of cellulose nanocrystals produce films with lower aw values. Similar results were obtained by Costa et al..$^{[6]}$, namely, aw values of $0.44-0.49$ for manioc films containing propolis extracts and reinforced with licuri cellulose nanocrystals.

All the films of the present study containing coconut cellulose nanocrystals were found to exhibit significantly higher humidity contents compared to the control films. The humidity of the films produced from the control formulation FM was $15.31 \%$, while those of the films produced from the manioc starch formulations containing cellulose nanocrystals varied between $16.21 \%$ and $18.33 \%$. Similar humidity values were obtained for the films produced from the potato starch formulations containing cellulose nanocrystals. The humidity of the films produced from the control formulation FB was $16.60 \%$, while those of the films produced from the other formulations varied between 18.26 and $18.87 \%$. These results indicate that the addition of coconut cellulose nanocrystals dispersed in water increased the humidity of the films. Considering the similar preparation conditions (amount of polymeric matrix, amount of plasticizer, and duration of drying), the higher humidity of the films containing cellulose nanocrystals may be due to the storage for ten days in a desiccator containing saturated sodium chloride solution before the characterization. The films containing the cellulose nanocrystals might have absorbed more water in the desiccator than the control films. Another possible explanation is that the nanocrystals that were incorporated into the plasticized polymeric matrix were dispersed in water, which could have increased the humidity of the films compared to the control films.

Expectedly, the strength and strain at breakage of the starch films were increased by the addition of the cellulose nanocrystals, as indicated in Table 4 and also previously reported ${ }^{[6,56,57]}$. The implied enhanced resistance to rupture is desirable and broadens the potential applications of the films to packaging and coating ${ }^{[17]}$. The strengths of the films ranged between $3.23 \mathrm{MPa}$ (control FM) and $8.20 \mathrm{MPa}$ (FB05). An increase of the cellulose nanocrystal concentration was not observed to increase the rupture resistance of the films, indicating that the addition of a large amount of nanoparticles could be counterproductive through their aggregation $^{[58]}$. For the manioc starch films, the optimal nanocrystal concentration for mechanical reinforcement was determined to be $1.0 \%$, while it was $0.5 \%$ for the potato starch films. In the case of the control films, those produced from potato starch were stronger. Overall, the potato starch films containing cellulose nanocrystals were generally the strongest. The mechanical properties of starch are known to be significantly affected by their botanical origin, specifically the native amylose and amylopectin contents ${ }^{[5]}$. The present observed film strengths could thus be explained by the fact that the molecular interactions among the starch chains, plasticizer, and dispersed nanocrystals in the potato starch films were more efficient. This may be due to the better 
dispersion of the nanocrystals within the matrix and stronger interfacial adhesion among the components of the complex system, which included the starch, glycerol, and nanocrystals. Similar strength results were obtained by Alves et al. ${ }^{[17]}$, who investigated the incorporation of eucalyptus nanocrystals in maze starch matrixes containing gelatin. They observed better dispersion of the nanocrystals in films with higher gelatin contents, resulting in better mechanical properties. Oun et al. ${ }^{[60]}$ also observed higher strength values of 22.7-33.7 MPa for agar-based nanocomposites and cotton cellulose nanocomposites. They found that the film traction increased with increasing nanocrystal concentration from $1 \%$ to $5 \%$, but decreased significantly $(p<0.05$ ) for $10 \%$ nanocrystals. Similar reports have been made by other researchers regarding the tensile properties of films with different matrixes containing cellulose nanocrystals ${ }^{[61-66]}$.

The determined values of the strain at breakage ranged between $17.54 \%$ (FM10) and 30.81\% (control FB). It was observed that the two strongest film types (FB05 and FM10) also exhibited the lowest breakage strains. This may be attributed to the higher rigidity of the films due to the strong interactions among the nanocrystals, plasticizer, and polymeric matrix. A small strain at breakage has actually been reported to be an indication of good interaction between the starch and nanocrystals ${ }^{[54,67,68]}$.

\section{Conclusions}

The combination of the availability of lignocellulosic fibers and the need for renewable resources for the production of polymers affords strong opportunities for adding value to agricultural products through technological innovation. The results of this study, as well as those of previous works, specifically confirm the viability of developing biodegradable polymeric packaging with adequate characteristics. The nanobiocomposite biodegradable films developed in the present study exhibited desirable barrier and mechanical properties including good transparency, manageability, homogeneity, adequate solubility, and high strength. The addition of cellulose nanocrystals obtained from green coconut fiber to the polymeric matrixes particularly afforded efficient mechanical reinforcement. A low or moderate nanocrystal concentration was found to be more effective depending on the type of polymeric matrix (potato or manioc starch), with higher concentrations inducing undesirable agglomeration of the nanocrystals. The best barrier and mechanic properties were exhibited by the films produced using potato starch, attributable to the better interactions among the polymeric matrix, the cellulose nanocrystals, and the employed plasticizer. It should be noted, though, that the optimal composition of the formulation used to develop the film would depend on the intended use and application technique.

\section{Acknowledgements}

The authors greatly appreciate the funding of this study by the National Service of Industrial Learning (Serviço Nacional de Aprendizagem Industrial) of the Regional Department of Bahia, the Foundation for Support to Research in Bahia (Fundação de Amparo a Pesquisa do
Estado da Bahia (FAPESB)), and the National Council of Technological and Scientific Development (CNPq). They also thank the Gonçalo Moniz Research Centre Fiocruz (Bahia) for their assistance with the microscopy analyses.

\section{References}

1. Bueno, R. L. C. (2010). Estudo da biodegradação do potencial de utilização de polilactato (PLA) como embalagem para alimento fermentado (Dissertação de mestrado). Centro de Ciências Tecnológicas, Universidade Regional de Blumenau, Blumenau.

2. Mali, S., Grossmann, M. V. E., \& Yamashita, F. (2010). Filmes de amido: produção, propriedades e potencial de utilização. Semina: Ciências Agrárias, 31(1), 137-156. http://dx.doi. org/10.5433/1679-0359.2010v31n1p137.

3. Debiagi, F., Ivano, L. R. P. F. M., Nascimento, P. H. A., \& Mali, S. (2012). Embalagens biodegradáveis de amido reforçadas com fibras lignocelulósicas provenientes de resíduos agroindustriais. BBR - Biochemistry and Biotechnology Reports, 1(2), 57-67. http://dx.doi.org/10.5433/2316-5200.2012.

4. Fiori, A. P. S. de M., Gabiraba, V. P., Praxedes, A. P. P., Nunes, M. R. S., Balliano, T. L., Silva, R. C. da, Tonholo, J., \& Ribeiro, A. S.. (2014). Preparação e caracterização de nanocompósitos poliméricos baseados em quitosana e argilo minerais. Polímeros: Ciência e Tecnologia, 24(5), 628-635. http://dx.doi.org/10.1590/0104-1428.1572.

5. Machado, B. A. S., Reis, J. H. O., Silva, J. B., Cruz, L. S., Nunes, I. L., Vargas, F. P., \& Druzian, J. I. (2014). Obtenção de nanocelulose da fibra de coco verde e incorporação em filmes biodegradáveis de amido plastificados com glicerol. Quimica Nova, 37(8), 1-8. http://dx.doi.org/10.5935/01004042.20140220 .

6. Costa, S. S., Druzian, J. I., Machado, B. A. S., De Souza, C. O., \& Guimarães, A. G. (2014). Bi-functional biobased packing of the cassava starch, glycerol, licuri nanocellulose and red propolis. PLoS One, 9(11), 112554. PMid:25383783. http:// dx.doi.org/10.1371/journal.pone.0112554.

7. Rhim, J. W., Park, H. M., \& Ha, C. S. (2013). Bio-nanocomposites for food packaging applications. Progress in Polymer Science, 38(10), 1629-1652. http://dx.doi.org/10.1016/j. progpolymsci.2013.05.008.

8. Tang, X. G., Kumar, P., Alavi, S., \& Sandeep, K. P. (2012). Recent advances in biopolymers and biopolymer-based nanocomposites for food packaging materials. Critical Reviews in Food Science and Nutrition, 52(5), 426-442. PMid:22369261. http://dx.doi.org/10.1080/10408398.2010.500508.

9. Shankar, S., \& Rhim, J. W. (2016). Preparation of nanocellulose from micro-crystalline cellulose: The effect on the performance and properties of agar-based composite films. Carbohydrate Polymers, 135, 18-26. PMid:26453846. http://dx.doi.org/10.1016/j. carbpol.2015.08.082

10. Machado, B. A. S., Nunes, I. L., Pereira, F. V., \& Druzian, J. I. (2012). Desenvolvimento e avaliação da eficácia de filmes biodegradáveis de amido de mandioca com nanocelulose como reforço e com extrato de erva-mate como aditivo antioxidante. Ciência Rural, 42(11), 2085-2091. http://dx.doi.org/10.1590/ S0103-84782012001100028.

11. Dantas, E. A., Costa, S. S., Cruz, L. S., Bramont, W. B., Costa, A. S., Padilha, F. F., Druzian, J. I., \& Machado, B. A. S. (2015). Characterization and evaluation of the antioxidant properties of biodegradable films incorporated with tropical fruit pulps. Ciência Rural, 45(1), 142-148. http://dx.doi.org/10.1590/0103$8478 \mathrm{cr} 20131458$. 
12. Silva, J. B. A., Nascimento, T., Costa, L. A. S., Pereira, F. V., Machado, B. A. S., Gomes, G. V. P., Assis, D. J., \& Druzian, J. I. (2015). Effect of source and interaction with nanocellulose cassava starch, glycerol and the properties of films bionanocomposites. Materials Today: Proceedings, 2(1), 200-207. https://doi.org/10.1016/j.matpr.2015.04.022.

13. Lomelí-ramírez, M. G., Kestur, S. G., Manríquez-González, R., Iwakiri, S., Muniz, G. B., \& Flores-Sahagun, T. S. (2014). Bio-composites of cassava starch-green coconut fiber: Part II-Structure and properties. Carbohydrate Polymers, 102, 576-583. PMid:24507321. http://dx.doi.org/10.1016/j. carbpol.2013.11.020.

14. Reis, L. C. B., Souza, C. O., Silva, J. B. A., Martins, A. C., Nunes, I. L., \& Druzian, J. I. (2015). Active biocomposites of cassava starch: The effect of yerba mate extract and mango pulp as antioxidant additives on the properties and the stability of a packaged product. Food and Bioproducts Processing, 94 , 382-391. http://dx.doi.org/10.1016/j.fbp.2014.05.004.

15. Agustin, M. B., Ahmmad, B., De Leon, E. R. P., Buenaobra, J. L., Salazar, J. R., \& Hirose, F. (2013). Starch-based biocomposite films reinforced with cellulose nanocrystals from garlic stalks. Polymer Composites, 34(8), 1325-1332. http://dx.doi.org/10.1002/pc.22546.

16. Savadekar, N. R., Karande, V. S., Vigneshwaran, N., Kadam, P. G., \& Mhaske, S. T. (2015). Preparation of cotton linter nanowhiskers by high-pressure homogenization process and its application in thermoplastic starch. Applied Nanoscience, 5(3), 281-290. http://dx.doi.org/10.1007/s13204-014-0316-3.

17. Alves, J. S., Reis, K. C., Menezes, E. G. T., Pereira, F. V., \& Pereira, J. (2015). Effect of cellulose nanocrystals and gelatin in corn starch plasticized films. Carbohydrate Polymers, 115, 215-222. PMid:25439888. http://dx.doi.org/10.1016/j. carbpol.2014.08.057.

18. Alemdar, A., \& Sain, S. (2008). Biocomposites from wheat straw nanofibers: morphology, thermal and mechanical properties. Composites Science and Technology, 68(2), 557-565. http:// dx.doi.org/10.1016/j.compscitech.2007.05.044.

19. Chen, W., Yu, H., Liu, Y., Chen, P., Zhang, M., \& Hai, Y. (2011). Individualization of cellulose nanofibers from wood using high-intensity ultrasonication combined with chemical pretreatments. Carbohydrate Polymers, 83(4), 1804-1811. http://dx.doi.org/10.1016/j.carbpol.2010.10.040.

20. Sá, R. M. D., Miranda, C. S. D., \& José, N. M. (2015). Preparation and characterization of nanowhiskers cellulose from fiber arrowroot (Maranta arundinacea). Materials Research, 18(suppl 2), 225-229. http://dx.doi.org/10.1590/1516-1439.366214.

21. Rambabu, N., Panthapulakkal, S., Sain, M., \& Dalai, A. K. (2015). Production of nanocellulose fibers from pinecone biomass: Evaluation and optimization of chemical and mechanical treatment conditions on mechanical properties of nanocellulose films. Industrial Crops and Products, 83, 746-754. http://dx.doi.org/10.1016/j.indcrop.2015.11.083.

22. Machado, B. A. S., Nunes, I. L., Vargas, F. V., \& Druzian, J. I. (2012). Desenvolvimento e avaliação da eficácia de filmes biodegradáveis de amido de mandioca com nanocelulose como reforço e com extrato de erva-mate como aditivo antioxidante. Ciência Rural, 42(11), 2085-2091. http://dx.doi.org/10.1590/ S0103-84782012001100028.

23. Pereira, F. V., Paula, E. L. D., Mesquita, J. P. D., Lucas, A. D. A., \& Mano, V. (2014). Bio-based nanocomposites obtained by incorporation of cellulose nanocrystals into biodegradable polymers through casting, layer-by-layer or electrospinning methods. Quimica Nova, 37(7), 1209-1219. http://dx.doi. org/10.5935/0100-4042.20140141.

24. Müller, C. M. O., Yamashita, F., \& Laurindo, J. B. (2008). Evaluation of the effects of glycerol and sorbitol concentration and water activity on the water barrier properties of cassava starch films through a solubility approach. Carbohydrate Polymers, 72(1), 82-87. http://dx.doi.org/10.1016/j.carbpol.2007.07.026.

25. Ishizaki, M. H., Visconte, L. L. Y., Furtado, C. R. G., Leite, M. C. A. M., \& Leblanc, J. L. (2006). Caracterização mecânica e morfológica de compósitos de polipropileno e fibras de coco verde: influência do teor de fibra e das condições de mistura. Polimeros: Ciência e Tecnologia, 16(3), 182-186. http://dx.doi. org/10.1590/S0104-14282006000300006.

26. Rosa, M. F., Medeiros, E. S., Malmonge, J. A., Gregorski, K. S., Wood, D. F., Mattoso, L. H. C., Glenn, G., Orts, W. J., \& Imam, S. H. (2010). Cellulose nanowhiskers from coconut husk fibers: effect of preparation conditions on their thermal and morphological behavior. Carbohydrate Polymers, 81(1), 83-92. http://dx.doi.org/10.1016/j.carbpol.2010.01.059.

27. Nascimento, D. M., Dias, A. F., Almeida, J. S., Morais, J. P. S., Souza, M. S. M., Fo., Figueiredo, M. C., \& Rosa, M. F. (2013). Nova abordagem para de obtenção de nanocristais de celulose a partir de um material rico em lignina. In Anais do VII Workshop de Nanotecnologia Aplicada ao AgronegócioInstrumentação (pp. 150-155). São Carlos: Embrapa.

28. Figueiredo, N. (2009). A importância dos selos verdes. São Paulo: IBDA. Retrieved in 2017, November 10, from http:// www.forumdaconstrucao.com.br/conteudo.php?a $=23 \& \operatorname{Cod}=694$

29. Oliveira, L. G. B., \& Moraes, M. F. V. (2007). O consumo consciente de embalagens sustentáveis. In Anais do $4^{\circ}$ Congresso Internacional de Pesquisa em Design Brasil (pp. 1-7). Rio de Janeiro: DesignBrasil.

30. Samir, A. S. A., Alloin, F., \& Dufresne, A. (2005). Review of recent research into cellulosic whiskers, their properties and their application in nanocomposite field. Biomacromolecules, 6(2), 612-626. PMid:15762621. http://dx.doi.org/10.1021/ bm0493685.

31. Van Soest, P. J., Robertson, J. B., \& Lewis, B. A. (1991). Methods for dietary fiber, neutral detergent fiber and nonstarch polysaccharides in relation to animal nutrition. Journal of Dairy Science, 74(10), 3583-3597. PMid:1660498. http:// dx.doi.org/10.3168/jds.S0022-0302(91)78551-2.

32. Goering, H. K., \& Van Soest, P. J. (1970). Forage fiber analysis - Apparatus, reagents, procedures and some applications: Agricultural Handbook. Beltsville: United States Department of Agriculture. Retrieved in 2017, Novomber 10, from http:/ naldc.nal.usda.gov/download/CAT87209099/PDF

33. Van-den-Berg, O., Capadona, J. R., \& Weder, C. (2007). Preparation of homogeneous dispersions of tunicate cellulose whiskers in organic solvents. Biomacromolecules, 8(4), 13531357. PMid:17343361. http://dx.doi.org/10.1021/bm061104q.

34. Veiga-Santos, P., Oliveira, L. M., Cereda, M. P., Alves, A. J., \& Scamparini, A. R. P. (2005). Mechanical properties, hydrophilicity and water activity of starch-gum films: effect of additives and deacetylated xanthan gum. Food Hydrocolloids, 19(2), 341-349. http://dx.doi.org/10.1016/j.foodhyd.2004.07.006.

35. Olivato, J. B., Mali, S., \& Grossmann, M. V. E. (2006). Efeito de embalagem biodegradável de amido no armazenamento de queijo processado. Ciências Agrárias, 27(1), 81-88. http:// dx.doi.org/10.5433/1679-0359.2006v27n1p81.

36. Gontard, N., Guilbert, S., \& Cuq, J. L. (1993). Water and glycerol as plasticizers affect mechanical and water vapor barrier properties of an edible wheat gluten film. Journal of Food Science, 58(1), 206-211. http://dx.doi.org/10.1111/j.1365-2621.1993. tb03246.x.

37. Fakhouri, F. M., Costa, D., Yamashita, F., Martelli, S. M., Jesus, R. C., Alganer, K., Collares-Queiroz, F. P., \& Innocentini-Mei, L. H. (2013). Comparative study of processing methods for starch/gelatin films. Carbohydrate Polymers, 95(2), 681-689. PMid:23648030. http://dx.doi.org/10.1016/j.carbpol.2013.03.027. 
38. Trugilho, P. F., Lima, J. T., \& Mendes, L. M. (1996). Influência da idade nas características físico-químicas e anatômicas da madeira de Eucalyptus saligna. Revista Cerne, 2(1), 94-111.

39. Corradini, E., Rosa, M. F., Macedo, B. P., Paladin, P. D., \& Mattoso, L. H. C. (2009). Composição química, propriedades mecânicas e térmicas da fibra de frutos de cultivares de coco verde. Revista Brasileira de Fruticultura, 31(3), 837-846. http://dx.doi.org/10.1590/S0100-29452009000300030.

40. Rosa, M. F., Medeiros, E. S., Imam, S. H., Nascimento, D. M., Monteiro, A. K., Malgonge, J. A., \& Mattoso, L. H. C. (2009). Nanocelulose de fibras de coco imaturo para aplicação em nanocompósitos. In Anais do V Workshop de Rede Nanotecnologia Aplicada ao Agronegócio (p. 1-4). São Carlos: EMBRAPA.

41. Mesquita, J. P., Donnici, C. L., \& Pereira, F. V. (2010). Biobased nanocomposites from layer-by-layer assembly of cellulose nanowhiskers with chitosan. Biomacromolecules, 11(2), 473-480. PMid:20055503. http://dx.doi.org/10.1021/ bm9011985.

42. Cranston, E. D., \& Gray, D. G. (2008). Birefringence in spincoated films containing cellulose nanocrystals. Colloids and Surfaces. A, Physicochemical and Engineering Aspects, 325(1), 44-51. http://dx.doi.org/10.1016/j.colsurfa.2008.04.042.

43. Pinto, G. V. V. V., Abreu, C. A. M., Knoechelmann, A., \& Almeida, Y. M. B. (1999). Caracterização físico-química da superfície de filmes de poli (tereftalato de etileno). Polímeros: Ciência e Tecnologia, 9(4), 184-188. http://dx.doi.org/10.1590/ S0104-14281999000400030.

44. Dufresne, A., Paillet, M., Putaux, J. L., Canet, R., Carmona, F., Delhaes, P., \& Cui, S. (2002). Processing and characterization of carbon nanotube/poly(styrene-co-butyl acrylate) nanocomposites. Journal of Materials Science, 37(18), 3015-3023. http://dx.doi. org/10.1023/A:1019659624567.

45. Silva, R. M., Pereira, F. V., Mota, F. A., Watanabe, E., Soares, S. M., \& Santos, M. H. (2016). Dental glass ionomer cement reinforced by cellulose microfibers and cellulose nanocrystals. Materials Science and Engineering C, 58, 389-395. PMid:26478325. http://dx.doi.org/10.1016/j.msec.2015.08.041.

46. Henrique, C. M., Cereda, M. P., \& Sarmento, S. B. S. (2008). Características físicas de filmes biodegradáveis produzidos a partir de amidos modificados de mandioca. Ciência e Tecnologia de Alimentos, 28(1), 231-240.

47. Jansson, A., \& Thuvander, F. (2004). Influence of thickness on the mechanical properties for starch films. Carbohydrate Polymers, 56(4), 499-503. http://dx.doi.org/10.1016/j. carbpol.2004.03.019.

48. Xiong, H. G., Tang, S., Tang, H., \& Zou, P. (2008). The structure and properties of a starch-based biodegradable film. Carbohydrate Polymers, 71(2), 263-268. http://dx.doi. org/10.1016/j.carbpol.2007.05.035.

49. Perazzo, K. K. N. C. L., Vasconcelos-Conceição, A. C. V., Santos, J. C. P., Jesus-Assis, D., Souza, C. O., \& Druzian, J. I. (2014). Properties and antioxidant action of actives cassava starch films incorporated with green tea and palm oil extracts. PLoS One, 9(9), e105199. PMid:25251437. http://dx.doi. org/10.1371/journal.pone.0105199.

50. Jiang, S., Liu, C., Wang, X., Xiong, L., \& Sun, Q. (2016). Physicochemical properties of starch nanocomposite films enhanced by self-assembled potato starch nanoparticles. Lebensmittel-Wissenschaft + Technologie, 69, 251-257. http:// dx.doi.org/10.1016/j.lwt.2016.01.053.

51. Fakhouri, F. M., Fontes, L. C. B., Gonçalves, P. D. M., Milanez, C. R., Steel, C. J., \& Collares-Queiroz, F. P. (2007). Filmes e coberturas comestíveis compostas à base de amidos nativos e gelatina na conservação e aceitação sensorial de uvas Crimson.
Ciência e Tecnologia de Alimentos, 27(2), 369-375. http:// dx.doi.org/10.1590/S0101-20612007000200027.

52. Saberi, B., Thakur, R., Vuong, Q. V., Chockchaisawasdee, S., Golding, J. B., Scarlett, C. J., \& Stathopoulos, C. E. (2015). Optimization of physical and optical properties of biodegradable edible films based on pea starch and guar gum. Industrial Crops and Products, 86, 342-352.

53. Rubentheren, V., Ward, T. A., Chee, C. Y., \& Nair, P. (2015). Physical and chemical reinforcement of chitosan film using nanocrystalline cellulose and tannic acid. Cellulose, 22(4), 2529-2541. http://dx.doi.org/10.1007/s10570-015-0650-y.

54. Pagno, C. H., Costa, T. M. H., Menezes, E. W., Benvenutti, E. V., Hertz, P. F., Matte, C. R., \& Flôres, S. H. (2015). Development of active biofilms of quinoa (Chenopodium quinoa W.) starch containing gold nanoparticles and evaluation of antimicrobial activity. Food Chemistry, 173, 755-762. PMid:25466086. http:// dx.doi.org/10.1016/j.foodchem.2014.10.068.

55. Silva, J., Pereira, F. V., \& Druzian, J. I. (2012). Cassava starch $\square$ based films plasticized with sucrose and inverted sugar and reinforced with cellulose nanocrystals. Journal of Food Science, 77(6), 14-19. PMid:22582979. http://dx.doi. org/10.1111/j.1750-3841.2012.02710.x.

56. Salaberria, A. M., Labidi, J., \& Fernandes, S. C. (2014). Chitin nanocrystals and nanofibers as nano-sized fillers into thermoplastic starch-based biocomposites processed by meltmixing. Chemical Engineering Journal, 256, 356-364. http:// dx.doi.org/10.1016/j.cej.2014.07.009.

57. Moura, M. R. D., Aouada, F. A., Souza, J. R., \& Mattoso, L. H. C. (2014). Preparação de novos nanobiocompósitos comestíveis ativos contendo nanoemulsão de canela e pectina. Polimeros Ciência e Tecnologia, 24(4), 486-490. http://dx.doi. org/10.1590/0104-1428.1508.

58. Chen, Y., Liu, C., Chang, P. R., Anderson, D. P., \& Huneault, M. A. (2009). Pea starch-based composite films with pea hull fibers and pea hull fiber-derived nanowhiskers. Polymer Engineering and Science, 49(2), 369-378. http://dx.doi. org/10.1002/pen.21290.

59. Hulleman, S. H., Janssen, F. H., \& Feil, H. (1998). The role of water during plasticization of native starches. Polymer, 39(10), 2043-2048. http://dx.doi.org/10.1016/S0032-3861(97)00301-7.

60. Oun, A. A., \& Rhim, J. W. (2015). Effect of post-treatments and concentration of cotton linter cellulose nanocrystals on the properties of agar-based nanocomposite films. Carbohydrate Polymers, 134, 20-29. PMid:26428095. http://dx.doi.org/10.1016/j. carbpol.2015.07.053

61. Chang, P. R., Jian, R., Yu, J., \& Ma, X. (2010). Starch-based composites reinforced with novel chitin nanoparticles. Carbohydrate Polymers, 80(2), 420-425. http://dx.doi. org/10.1016/j.carbpol.2009.11.041.

62. Savadekar, N. R., Karande, V. S., Vigneshwaran, N., Kadam, P. G., \& Mhaske, S. T. (2015). Preparation of cotton linter nanowhiskers by high-pressure homogenization process and its application in thermoplastic starch. Applied Nanoscience, 5(3), 281-290. http://dx.doi.org/10.1007/s13204-014-0316-3.

63. Reddy, J. P., \& Rhim, J. W. (2014). Characterization of bionanocomposite films prepared with agar and paper-mulberry pulp nanocellulose. Carbohydrate Polymers, 110, 480-488. PMid:24906782. http://dx.doi.org/10.1016/j.carbpol.2014.04.056.

64. Xu, X., Wang, H., Jiang, L., Wang, X., Payne, S. A., Zhu, J. Y., \& Li, R. (2014). Comparison between cellulose nanocrystal and cellulose nanofibril reinforced poly(ethylene oxide) nanofibers and their novel shish-kebab-like crystalline structures. Macromolecules, 47(10), 3409-3416. http://dx.doi. org $/ 10.1021 / \mathrm{ma} 402627 \mathrm{j}$.

65. Rhim, J. W., Reddy, J. P., \& Luo, X. (2015). Isolation of cellulose nanocrystals from onion skin and their utilization 
for the preparation of agar-based bio-nanocomposites films Cellulose, 22(1), 407-420. http://dx.doi.org/10.1007/s10570014-0517-7.

66. Chang, P. R., Jian, R., Yu, J., \& Ma, X. (2010). Starch-based composites reinforced with novel chitin nanoparticles. Carbohydrate Polymers, 80(2), 420-425. http://dx.doi. org/10.1016/j.carbpol.2009.11.041.

67. Lu, Y., Weng, L., \& Cao, X. (2006). Morphological, thermal and mechanical properties of ramie crystallites-reinforced plasticized starch biocomposites. Carbohydrate Polymers, 63(2), 198-204. http://dx.doi.org/10.1016/j.carbpol.2005.08.027.
68. Azeredo, H. M. C., Mattoso, L. H. C., Wood, D., Williams, T. G., Avena $\square$ Bustillos, R. J., \& McHugh, T. H. (2009). Nanocomposite edible films from mango puree reinforced with cellulose nanofibers. Journal of Food Science, 74(5), N31-N35. PMid:19646052. http://dx.doi.org/10.1111/j.17503841.2009.01186.x.

Received: Apr. 22, 2016

Revised: Dec. 03, 2016

Accepted: Dec. 12, 2016 